\title{
IMPLEMENTASI PENDEKATAN PROBLEM POSING SOAL MATEMATIKA PISA LIKES TERHADAP KEMAMPUAN LITERASI MATEMATIS
}

\section{IMPLEMENTATION OF PROBLEM POSING APROACH USING MATHEMATICS QUESTIONS PISA LIKES TOWARD MATHEMATICAL LITERACY}

\author{
Risdiana Chandra Dhewy ${ }^{1}$, Nurina Ayuningtyas ${ }^{2}$ \\ 1 STKIP PGRI SIDOARJO, chandra.statistika.its@gmail.com \\ 2 STKIP PGRI SIDOARJO, nurinaayu.n@gmail.com
}

\begin{abstract}
Abstrak. Pendekatan problem posing (PPS) sejalan dengan tujuan kurikulum pendidikan matematika di Indonesia, yang memberikan bekal kepada siswa untuk berpikir logis, kritis, cermat, kreatif dan disiplin serta mengetahui kegunaan matematika dalam kehidupan nyata. Penelitian ini menuntut mahasiswa calon guru matematika untuk mengajukan soal matematika PISA likes guna memperkaya wawasan tentang literasi matematis. Tujuan dari penelitian ini untuk mengetahui dan mendeskripsikan aktifitas guru, aktivitas mahasiswa, hasil belajar mahasiswa dan respon mahasiswa serta untuk melihat kemampuan literasi mahasiswa calon guru. Jenis penelitian ini merupakan penelitian experiment dengan one group pretest-posttest design. Sampel yang digunakan sebanyak 31 mahasiswa jurusan pendidikan matematika STKIP PGRI Sidoarjo semester 6. Hasil dari penelitian ini yaitu aktifitas guru dinyatakan sangat baik dengan score 3.5, aktifitas siswa tergolong aktif, hasil belajar mahasiswa meningkat dengan demikian dapat disimpulkan kemampuan literasi matematis mahasiswa calon guru juga mengalami peningkatan dan mahasiswa memberikan respon positif terhadap pembelajaran PPS.
\end{abstract}

Kata kunci: problem posing, PISA, literasi matematis

Abstract. The problem posing (PPS) approach is in line with the aims of the mathematics education curriculum in Indonesia, which provides students with the ability to think logically, critically, carefully, creatively and disciplined as well as knowing the usefulness of mathematics in real life. This study requires prospective mathematics teacher students to submit mathematical problems PISA likes in order to enrich insights about mathematical literacy. The purpose of this study is to determine and describe the teachers activities, students activities, student learning outcomes and student responses and to see 
the literacy abilities of prospective teacher students. This type of research is an experimental study with one group pretest-posttest design. The sample used was 31 students majoring in mathematics education STKIP PGRI Sidoarjo in the 6th semester. The results of this study were teacher activity was stated to be very good with a score of 3.5, student activity was classified as active, student learning outcomes improved thus it can be concluded that the mathematical literacy ability of prospective teacher was also get improvement and students give positive responses to PPS learning.

Keywords: Problem Posing, PISA, Mathematical Literacy

\section{PENDAHULUAN}

PISA adalah Programme for International Students Assessment yang mengadakan survey untuk beberapa siswa usia 15 tahun di berbagai Negara dan salah satunya Indonesia. Peringkat literasi matematis siswa Indonesia dalam hasil survey PISA sejak tahun 2009 hingga 2015 tidak menunjukan adanya kenaikan yang signifikan. Tahun 2009 Indonesia berada pada peringkat 68 dari 74 negera. Selanjutnya pada tahun 2012 Indonesia berada di peringkat 64 dari 65 negara dengan tingkat pencapaian relatif rendah. Sedangkan hasil PISA di tahun 2015 menunjukan peringkat Indonesia mengalami sedikit kenaikan urutan yaitu 63 dari 72 negara. Hasil selama tiga kali survey menunjukan kemampuan peserta didik di Indonesia pada literasi matematis khususnya masih tergolong sangat rendah dibandingkan dengan negara peserta PISA lainnya.

Hasil yang rendah dimungkinkan siswa Indonesia hanya terbiasa dengan soal-soal rutin seperti menyelesaikan soal matematika dengan rumus. Hasil yang rendah tersebut juga disebabkan tidak semua guru matematika di sekolah mengetahui tentang soal-soal matematika model PISA. Berbagai upaya kementrian pendidikan mengatasi masalah ini dengan memberikan pelatihan/workshop literasi matematis dan bagaimana mengajukan soal matematika model PISA kepada guru matematika. Persiapan lain yang dapat dilakukan yaitu 
membekali mahasiswa pendidikan matematika dengan mengimplementasikan pendekatan problem posing PISA likes pada mata kuliah matematika sekolah. Pada mata kuliah matematika sekolah mahasiswa belajar materi-materi yang akan mereka ajarkan ketika di sekolah kelak. Materi yang mereka pelajari antara lain matematika SMP dan matematika SMA.

Pendekatan problem posing dipilih sebab sejalan dengan tujuan kurikulum pendidikan matematika, seperti pembelajaran matematika memberikan bekal kepada siswa berpikir logis, kritis, cermat, kreatif dan disiplin serta menghargai kegunaan matematika (Siswono, 2018). Mestre (dalam Christaou, dalam Siswono:2018) mengemukakan problem posing sebagai sarana untuk melatih proses berpikir, beliau juga menjelaskan problem posing dapat dimanfaatkan untuk menransfer konsep melalui konteks dan mengidentifikasi pengetahuan, penalaran dan pengembangan konsep. Problem Posing juga sebagai alat komunikasi matematika dan memacu siswa lebih bertanggung jawab dalam belajarnya (English, 1997).

Lavy dan Bershadsky (2003) mengatakan penggunaan pendekatan problem posing memberikan kontribusi pada perkembangan wawasan matematika. Selanjutnya penelitian yang dilakukan oleh Barlow dan Cates (2006) menyimpulkan guru yang menerapkan problem posing dapat menjadikan suasana kelas berpusat pada siswa dan menjadikan siswa lebih aktif untuk membuat dan menyelesaikan masalah. Disamping itu, Cunningham (Within: 2006) menjelaskan siswa yang menciptakan masalah baru dapat meningkatkan rasa tanggung jawab dan membangun pengetahuan sendiri sambil mengkritik dan memperbaiki masalah yang diajukan oleh teman sebaya. Dengan demikian mendorong siswa untuk sharing dan memberikan saran ide-ide yang diajukan. Seorang pendidik dapat mengembangkan disposisi dan keterampilan inkuiri yang dibutuhkan peserta didik untuk membantu mereka mengembangkan 
problem posing yang efektif (English, 1997; Gonzales, 1998; Silver, 1994).

Pada penelitian ini, peneliti menggunakan pendekatan problem posing untuk mengajukan soal matematika model PISA pada mata kuliah matematika sekolah. Soal matematika model PISA adalah soal kontekstual yang menuntut siswa menyelesaikan permasalahan matematika dan dapat digunakan untuk mengetahui kemampuan literasi siswa. Soal matematika model PISA mencakup proses matematika, konten, konteks, dan memiliki enam level soal.

Proses matematika menjabarkan kegiatan siswa ketika menghubungkan masalah kontekstual dengan matematika dan menyelesaikannya serta meliputi kemampuan yang mendasari setiap proses. Berdasarkan definisi literasi matematis PISA 2012 proses matematika digolongkan menjadi tiga antara lain kemampuan dalam formulate (menformulasikan), employ (menerapkan), dan interprete (menafsirkan).

Konten matematika dalam PISA dibagi menjadi empat dalam OECD (2013) yaitu change and relationship (perubahan dan keterkaitan), space and shape (ruang dan bentuk), quantity (bilangan), dan uncertainty and data (ketidakpastian dan data). PISA yang menekankan pada konteks kehidupan sehari-hari maka mathematical contexts digolongkan menjadi empat macam konteks yaitu personal (pribadi), societal (social), occupation (pekerjaan), dan scientific (ilmu pengetahuan).

Menurut Setiawan (2014:247) soal literasi matematika level 1 dan 2 termasuk kelompok soal dengan skala rendah, kemudian soal literasi matematika level 3 dan 4 termasuk kelompok soal dengan skala sedang, dan soal literasi matematika level 5 dan 6 termasuk kelompok soal dengan skala tinggi dengan konteks yang sama sekali tidak terduga oleh siswa. PISA menetapkan kemampuan matematis siswa dengan level 1 sampai 6.

Dengan soal matematika model PISA pendidik dapat mengetahui kemampuan literasi matematis siswa. Definisi yang diungkapkan oleh 
PISA dalam OECD (2014), literasi matematis diartikan sebagai kemampuan seseorang untuk merumuskan, menerapkan dan menafsirkan matematika dalam berbagai konteks, termasuk penalaran matematis dan penggunaan konsep matematika, prosedur, fakta dan alat untuk mendeskripsikan, menjelaskan, dan memprediksi fenomena. Literasi matematika membantu seseorang untuk mengenal peran matematika dalam kehidupan sehari- hari dan membuat keputusan yang baik dan dibutuhkan keterlibatan masyarakat secara konstruktif dan reflektif. Alat yang dimakud dalam definisi literasi matematis adalah media yang digunakan untuk memahami konsep dan menyelesaikan persoalan matematika seperti penggaris, busur, jangka, kalkulator, serta media lainnya.

Dalam penelitian ini mahasiswa jurusan pendidikan matematika diberikan pembelajaran pada mata kuliah matematika sekolah dengan pendekatan problem posing. Peneliti juga memberikan materi tentang literasi matematika dan bagaimana mengajukan soal matematika model PISA. Mahasiswa calon guru diberikan tugas untuk berdiskusi mengajukan soal matematika model PISA beserta penyelesaiannya yang terfokus pada konten matematika dan proses matematika. Peneliti membebaskan mahasiswa calon guru matematika untuk memilih level dan konteks dari soal matematika model PISA. Hasil dari diskusi pengajuan soal yang telah dibuat, ditukar dengan kelompok lain untuk dikerjakan dan diberikan komentar apakah soal yang diajukan sudah sesuai dengan konten matematika, proses matematika beserta penyelesaiannya. Tujuan dari penelitian ini untuk mengetahui dan mendeskripsikan aktifitas guru, aktivitas mahasiswa, hasil belajar mahasiswa dan respon mahasiswa serta untuk melihat kemampuan literasi mahasiswa calon guru. 


\section{METODE PENELITIAN}

Penelitian ini termasuk ke dalam jenis penelitian experiment dengan menggunakan one group pretest posttest design. Sampel yang digunakan sebanyak 31 mahasiswa semester 6 dari Program Studi Pendidikan Matematika STKIP PGRI Sidoarjo. Instrumen yang digunakan meliputi lembar observasi guru, lembar observasi mahasiswa, lembar tes yang terdiri dari lembar pretest dan posttest serta yang terakhir yaitu lembar angket respons mahasiswa. Soal matematika PISA tahun 2006-2012 yang diterjemahkan ke dalam bahasa indonesia diadopsi untuk dijadikan soal pretest dan posttest. Instrumen yang digunakan dalam penelitian ini meliputi lembar observasi aktifitas guru, lembar observasi aktifitas mahasiswa, soal pretest-posttest serta angket respon. Prosedur penelitian ini meliputi pemberian soal pretest kepada mahasiswa, pemberian treatment berupa pendekatan Problem Posing PISA Likes, pemberian soal posttest, dan yang terakhir pemberian angket respons.

\section{HASIL DAN PEMBAHASAN}

Hasil dan pembahasan dalam penelitian ini meliputi aktivitas guru, aktivitas mahasiswa, hasil belajar, dan respons mahasiswa. Sebelum diimplementasikan pendekatan Problem Posing, mahasiswa terlebih dahulu diberikan pretest untuk mengukur kemampuan mereka dalam menyelesaikan soal PISA. Soal tes yang diberikan sebanyak 24 soal yang diadopsi dari soal PISA tahun 2006-2012 yang terdiri dari 4 konten soal meliputi change and relationship, quantity, uncertainty and data, dan space and shape. Setelah dilakukan pretest, guru memulai kegiatannya. Untuk analisis yang pertama yaitu analisis deskriptif tentang aktivitas guru selama kegiatan pembelajaran dengan menerapkan Problem Posing. Kegiatan observasi guru ini dilakukan sebanyak 3 kali observasi di kelas dengan hasil yang tercantum pada Tabel 1. sebagai berikut : 
Tabel 1. Hasil Observasi Aktivitas Guru

\begin{tabular}{|c|c|c|c|}
\hline No & Aspek yang diamati & Rata-rata tiap aspek & Kategori \\
\hline 1 & Persiapan & 3,35 & Baik \\
\hline \multirow[t]{4}{*}{2} & Pelaksanaan & & \\
\hline & - $\quad$ Pendahuluan & 3,2 & Baik \\
\hline & - $\quad$ Kegiatan inti & 3,7 & Sangat baik \\
\hline & - $\quad$ Penutup & 4 & Sangat baik \\
\hline 3 & Pengelolaan waktu & 3,3 & Baik \\
\hline 4 & Suasana kelas & 3,6 & Sangat baik \\
\hline & Rata-rata & 3,52 & Sangat baik \\
\hline
\end{tabular}

Berdasarkan hasil analisis data deskriptif diperoleh rata-rata

keselurahan dari aspek yang diamati sebesar 3,52, nilai tersebut berada pada kategori sangat baik untuk aktivitas guru selama diterapkannya pendekatan Problem Posing di kelas. Sedangkan untuk aktivitas mahasiswa selama pembelajaran yang diamati dari 9 indikator tercantum dalam Tabel 2. sebagai berikut :

Tabel 2. Hasil Observasi Aktivitas Mahasiswa

\begin{tabular}{|c|c|c|c|c|c|c|c|}
\hline \multirow{2}{*}{ No } & \multirow{2}{*}{ Indikator } & \multicolumn{3}{|c|}{ Pertemuan } & \multirow{2}{*}{$\begin{array}{c}\text { Rata- } \\
\text { rata }\end{array}$} & \multirow{2}{*}{ Persentase } & \multirow{2}{*}{ Kriteria } \\
\hline & & 1 & 2 & 3 & & & \\
\hline 1 & $\begin{array}{l}\text { Mahasiswa memperhatikan } \\
\text { guru menyampaikan materi } \\
\text { pelajaran }\end{array}$ & 90 & 91 & 93 & 91,3 & $73,7 \%$ & Aktif \\
\hline 2 & $\begin{array}{l}\text { Mahasiswa berdiskusi } \\
\text { untuk membuat soal PISA } \\
\text { Likes dengan kelompoknya } \\
\text { masing-masing }\end{array}$ & 92 & 92 & 92 & 92,0 & $74,2 \%$ & Aktif \\
\hline 3 & $\begin{array}{l}\text { Mahasiswa saling berbagi } \\
\text { informasi, ide maupun } \\
\text { gagasan pada soal tersebut }\end{array}$ & 91 & 91 & 91 & 91,0 & $73,4 \%$ & Aktif \\
\hline 4 & $\begin{array}{l}\text { Mahasiswa saling bekerja } \\
\text { sama untuk menjawab soal- } \\
\text { soal PISA Likes tersebut }\end{array}$ & 92 & 91 & 92 & 91,7 & $73,9 \%$ & Aktif \\
\hline 5 & $\begin{array}{l}\text { Tiap kelompok saling } \\
\text { menukarkan lembar soal } \\
\text { tersebut dengan kelompok } \\
\text { lain }\end{array}$ & 93 & 93 & 93 & 93,0 & $75,0 \%$ & Aktif \\
\hline 6 & $\begin{array}{l}\text { Mahasiswa saling bekerja } \\
\text { sama untuk menyelesaikan } \\
\text { soal-soal yang diberikan } \\
\text { oleh kelompok lain }\end{array}$ & 93 & 93 & 93 & 93,0 & $75,0 \%$ & Aktif \\
\hline 7 & $\begin{array}{l}\text { Mahasiswa } \\
\text { mempresentasikan hasil } \\
\text { jawaban soal dan hasil } \\
\text { diskusi tiap kelompok }\end{array}$ & 102 & 101 & 101 & 101,3 & $81,7 \%$ & $\begin{array}{c}\text { Sangat } \\
\text { aktif }\end{array}$ \\
\hline
\end{tabular}




\begin{tabular}{|c|l|c|c|c|c|c|c|}
\hline \multirow{2}{*}{ No } & \multicolumn{1}{|c|}{ Indikator } & \multicolumn{3}{|c|}{ Pertemuan } & \multirow{2}{*}{$\begin{array}{c}\text { Rata- } \\
\text { rata }\end{array}$} & Persentase & Kriteria \\
\cline { 2 - 5 } 8 & 1 & 2 & 3 & & & \\
\hline & $\begin{array}{l}\text { Mahasiswa saling bertukar } \\
\text { pendapat dan memberikan } \\
\text { saran atas penyelesaian soal } \\
\text { yang dianggap sulit dalam } \\
\text { kegiatan diskusi kelas }\end{array}$ & 93 & 93 & 93 & 93,0 & $75,0 \%$ & Aktif \\
\hline 9 & $\begin{array}{l}\text { Mahasiswa menyimpulkan } \\
\text { hasil diskusi dari soal yang } \\
\text { mereka kerjakan }\end{array}$ & 93 & 93 & 93 & 93,0 & $75,0 \%$ & Aktif \\
\hline
\end{tabular}

Dari 9 aspek yang diamati ternyata diperoleh hasil bahwa aktivitas mahasiswa dari 8 aspek yang diamati selama kegiatan pembelajaran berada pada kategori aktif sedangkan 1 aspek lainnya berada pada kategori sangat aktif yaitu ketika guru meminta mahasiswa untuk mempresentasikan hasil jawaban soal dan hasil diskusi dari masingmasing kelompok. Setelah dilakukan observasi guru dan mahasiswa selama 3 kali pertemuan, peneliti memberikan posttest kepada mahasiswa terdiri dari 4 konten dan soal yang diberikan sebanyak 24 nomor soal. Setelah dilakukan analisis terhadap hasil belajar siswa, diketahui bahwa terdapat peningkatan hasil belajar siswa sebelum dan sesudah diimplementasikan pendekatan Problem Posing dengan nilai sebagai berikut :

Tabel 3. Hasil Deskriptif Statistik

\section{Descriptive Statistics}

\begin{tabular}{lr|r|r|r} 
& $\mathrm{N}$ & \multicolumn{1}{c|}{ Minimum } & Maximum & \multicolumn{1}{c}{ Mean } \\
\hline Pretest & 31 & 13 & 80 & 50,10 \\
\hline Posttest & 31 & 40 & 67 & 56,58 \\
\hline Valid N (listwise) & 31 & & & \\
\hline
\end{tabular}

Pada tahap pretest rata-rata hasil belajar mahasiswa sebesar 50,10 sedangkan pada tahap posttest terjadi peningkatan dengan nilai rata-rata menjadi 56,58. Meskipun nilai rata-rata hasil belajar tersebut masih jauh dari estimasi yang diharapkan peneliti, setidaknya mahasiswa sudah berusaha untuk menunjukkan peningkatan hasil setelah mereka berlatih pengajuan soal PISA Likes. Selain dianalisis dengan menggunakan 
deskriptif statistik, peneliti juga melakukan uji hipotesis dari data hasil belajar mahasiswa baik pretest maupun posttest. Analisis yang digunakan dalam penelitian ini yaitu analisis komparatif dua sampel dependen. Sebelum dilakukan analisis tersebut terlebih dahulu dilakukan uji normalitas menggunakan Kolmogorov-Smirnov. Tujuan dilakukannya uji normalitas untuk mengetahui apakah penyebaran data dari nilai hasil belajar menyebar normal ataukah tidak. Hipotesis yang digunakan adalah sebagai berikut :

$\mathrm{H}_{0}$ : data berdistribusi normal

$\mathrm{H}_{1}$ : data tidak berdistribusi normal

Berdasarkan hasil analisis uji normalitas dengan menggunakan Kolmogorov-Smirnov yang tercantum pada Tabel 1. dapat diketahui bahwa p-value pada tahap pretest sebesar 0,109 dan pada tahap posttest sebesar 0,112, kedua nilai tersebut lebih dari 0,05 yang berarti $\mathrm{H}_{0}$ diterima sehingga dapat disimpulkan data berdistribusi normal atau terpenuhinya asumsi normalitas data.

Tabel 4. Uji Normalitas Data

Tests of Normality

\begin{tabular}{lr|r|r|r|r|r} 
& \multicolumn{3}{c}{ Kolmogorov-Smirnova } & \multicolumn{3}{c}{ Shapiro-Wilk } \\
& Statistic & Df & \multicolumn{1}{c}{ Sig. } & Statistic & df & \multicolumn{1}{c}{ Sig. } \\
\hline Pretest &, 143 & 31 &, 109 &, 971 & 31 &, 534 \\
\hline Posttest &, 142 & 31 &, 112 &, 937 & 31 &, 070 \\
\hline
\end{tabular}

a. Lilliefors Significance Correction

Dengan terpenuhinya asumsi normalitas, maka langkah selanjutnya dilakukan uji komparatif dua sampel dependen dengan hipotesis sesbagai berikut :

$\mathrm{H}_{0}$ : Tidak ada perbedaan rata-rata hasil belajar mahasiswa yang dilihat dari kemampuan literasi matematis sebelum dan sesudah diterapkannya Problem Posing PISA Likes

$\mathrm{H}_{1}$ : Ada perbedaan rata-rata hasil belajar mahasiswa yang dilihat dari kemampuan literasi matematis sebelum dan sesudah diterapkannya 
Problem Posing PISA Likes

Dengan menggunakan $\alpha=0,05$, diperoleh nilai $t$ tabel sebagai berikut :

$$
\begin{aligned}
\mathrm{t}_{\text {tabel }} & =\frac{\alpha}{2} ;(n-1) \\
& =\frac{0,05}{2} ;(31-1) \\
& =2,042
\end{aligned}
$$

Berdasarkan hasil analisis data dengan menggunakan SPSS 24.0 pada Tabel 5, diperoleh nilai $t_{\text {hitung }}$ sebesar $-2,699$, karena nilai $t_{\text {hitung }}(-2,699) \leq-$ $\mathrm{t}$ tabel $(-2,042)$ maka dapat dinyatakan bahwa $\mathrm{H}_{0}$ ditolak. Selain menggunakan keputusan melalui thitung, pengambilan keputusan juga dapat dilakukan melalui p-value yaitu sebesar $(0,011)$, p-value tersebut kurang dari 0,05 sehingga $\mathrm{H}_{0}$ ditolak. Dari hasil pengambilan keputusan dapat disimpulkan bahwa ada perbedaan rata-rata hasil belajar mahasiswa yang dilihat dari kemampuan literasi matematis sebelum dan sesudah diterapkannya Problem Posing PISA Likes. Adanya perbedaan tersebut juga dapat dilihat dari peningkatan nilai pretest ke posttest mahasiswa. Hal ini menunjukkan bahwa pendekatan Problem Posing PISA Likes memberikan kontribusi terhadap kemampuan literasi matematis bagi mahasiswa calon guru.

Tabel 5. Uji Komparatif Dependen

\section{Paired Samples Test}

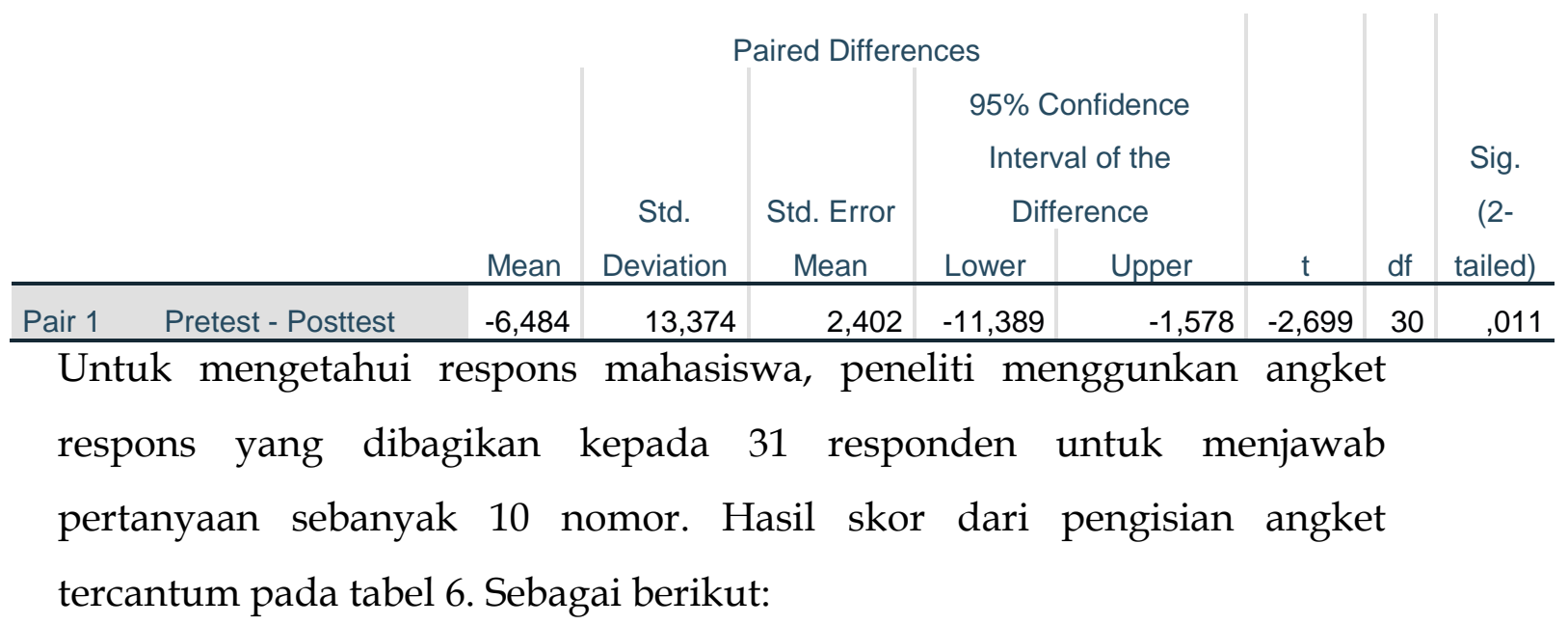


Tabel 6. Data Respons Mahasiswa

\begin{tabular}{cccccccc}
\hline $\begin{array}{c}\text { Item } \\
\text { soal }\end{array}$ & Skor 1 & Skor 2 & Skor 3 & Skor 4 & Total NRS & $\%$ NRS & $\begin{array}{c}\text { Kategori } \\
\text { Respons }\end{array}$ \\
\hline 1 & 0 & 0 & 51 & 32 & 83 & 67 & Baik \\
\hline 2 & 0 & 0 & 54 & 28 & 82 & 66 & Baik \\
\hline 3 & 0 & 6 & 54 & 16 & 76 & 61 & Baik \\
\hline 4 & 0 & 0 & 54 & 28 & 82 & 66 & Baik \\
\hline 5 & 0 & 4 & 60 & 12 & 76 & 61 & Baik \\
\hline 6 & 0 & 2 & 48 & 32 & 82 & 66 & Baik \\
\hline 7 & 2 & 4 & 48 & 20 & 74 & 60 & Baik \\
\hline 8 & 0 & 4 & 48 & 28 & 80 & 65 & Baik \\
\hline 9 & 0 & 0 & 42 & 44 & 86 & 69 & Baik \\
\hline 10 & 0 & 0 & 45 & 40 & 85 & 69 & Baik
\end{tabular}

Berdasarkan hasil analisis kuesioner dapat diketahui bahwa semua item pertanyaan memiliki kategori baik untuk respons mahasiswa terhadap pembelajaran sehingga respons dinyatakan positif dengan alasan kategori baik lebih dari atau sama dengan 50\% dari seluruh item pertanyaan. Dengan demikian Problem Posing PISA Likes memberikan kontribusi terhadap kemampuan literasi matematis mahasiswa calon guru.

\section{KESIMPULAN}

Berdasarkan hasil analisis data dapat simpulkan bahwa(1) aktivitas guru dinyatakan sangat baik dengan skor 3,5, (2) untuk aktivitas siswa tergolong aktif dari 8 indikator yang diobservasi dan 1 indikator tergolong sangat aktif yaitu ketika mahasiswa diminta guru untuk mempresentasikan hasil diskusi mereka, (3) untuk hasil belajar dinyatakan hasil belajar mahasiswa meningkat dengan demikian dapat disimpulkan kemampuan literasi matematis mahasiswa calon guru juga mengalami peningkatan (4) untuk respons mahasiswa dinyatakan memiliki respons positif terhadap pembelajaran menggunakan pendekatan Problem Posing PISA Likes dengan alasan bahwa semua item pertanyaan kuesioner berada pada kategori baik. Hal ini menunjukkan 
bahwa pendekatan Problem Posing PISA Likes memberikan kontribusi

terhadap kemampuan literasi matematis bagi mahasiswa calon guru.

\section{DAFTAR RUJUKAN}

Barlow, A. T., \& Cates, J. M. (2006). The impacts of problem posing on elementary teachers' belief about mathematics and mathematics teaching. School Science and Mathematics, 106, 64-73. http:/ / dx.doi.org/10.1111/j.1949-8594.2006.tb18136.x

English, Lyn D. (1997). "Promoting A Problem Posing Classroom". Teaching Children Mathematics, November 1997. p.172-179.

Lavy, I., \& Bershadsky, I. (2003). Problem posing via "what if not?" strategy in solid geometry-a case study. Journal of Mathematical Behavior,

369-387.

http:/ / dx.doi.org/10.1016/j.jmathb.2003.09.007

Misbahuddin dan I. Hasan. (2013). Analisis Data Penelitian Dengan Statistik. Jakarta : Bumi Aksara.

OECD. (2013). PISA 2012 Assessment and Analytical Framework: Mathematics,Reading, Science, Problem Solving and Financial Literacy. Paris: OECD Publishing.

OECD. (2014). PISA 2012 Result in Focus: What 15-year-olds know and what they cando with what they know.http://www.oecd.org/pisa/keyfindings/pisa-2012resultsoverview.pdf. diakses tanggal 15 September 2014 pukul 15.32 .

OECD. (2014). PISA 2012 Results: What Students Know and Can Do StudentPerformance in Mathematics, Reading and Science. Volume I. Paris: OECDPublishing.

Setiawan, dkk. (2014). Soal Matematika Dalam Pisa Kaitannya Dengan Literasi Matematik Dan Keterampilan Berpikir Tingkat Tinggi. Jember : Program Studi Pendidikan Matematika FKIP Universitas Jember

Silver, Edward A \& Cai, Jinfa (1996)." An Analysis of Arithmetic Problem Posing By Middle School Students". Journal For Research In Mathematics Education,Volume 27. No. 5, p. 521-539

Siregar, S. (2012). Statistik Parametrik untuk Penelitian Kuantitatif. Jakarta : PT. Bumi Aksara.

Siswono, T. Y. E. (2018). Pembelajaran Matematika Berbasis Pemecahan dan Pengajuan Masalah. Bandung : Rosda.

Within, D. J. (2006). Problem posing in the elementary classroom. Teaching Children Mathematics, 13(1), 14-18. 